ORIGINAL ARTICLE

\title{
Examination of the perceptions of self-sufficiency and burnout levels of students of the sports science faculty during the COVID-19 pandemic
}

\author{
Şakir Tüfekçi ${ }^{1 \mathrm{ABCDE}}$, Hulusi Böke ${ }^{2 \mathrm{ABCD}}$ \\ ${ }^{1}$ Sports Management Department, Malatya, Turkey \\ ${ }^{2}$ Ministry of Education, Yaşar Öncan Secondary School, Malatya, Turkey
}

Authors' Contribution: A - Study design; B - Data collection; C - Statistical analysis; D - Manuscript Preparation; E - Funds Collection.

\begin{abstract}
Background To determine the perception of self-sufficiency and burnout levels of students studying in the faculty of and Study Aim sports sciences during the Covid-19 pandemic.

Material and

Methods

This cross-sectional descriptive-correlational study was performed in the Sports Science Faculty of Inönü University of Turkey which forms the universe of the study. In addition, "Perception of General self-sufficiency" and "Burnout Level Scale" were used in the study. T-test and One-Way ANOVA tests were used to perform the differential analysis and Pearson Product Moment Correlation analysis was used to determine the correlation between variables. In addition, regression analysis was performed by creating dummy variables in order to predict the dimensions.

Results: $\quad$ The students' general self-sufficiency perception scores were found to be above average and their burnout levels were found to be below average. It was observed that the general self-sufficiency perception scores differed in terms of the class variable, and the burnout level scores differed in terms of class, family income level and studied department variables. In the correlation analysis that was carried out, it was understood that there was a mutually inverse and significant correlation between the dimensions of the scale. With the regression analysis, it was determined that the first-grade level scores were an independent significant predictor for both self-sufficiency and burnout scores, and the lowest income level scores were only an independent predictor for burnout level scores.

Conclusions It can be said that students at the faculty of sports sciences are not overly affected by the Covid-19 Pandemic and the results are as desired. It can be suggested that the perception of self-sufficiency and burnout scores to be correlated and predicted with different variables.

Keywords: $\quad$ COVID-19, sports sciences, general perception of self-sufficiency, burnout level, student.
\end{abstract}

\section{Introduction}

More than 1.5 billion students and young people worldwide have been affected by the closures of schools and universities due to the COVID-19 pandemic [1]. Students and lecturers in higher education institutions have been severely affected by unprecedented changes as a result of the Covid-19 pandemic [2]. Many prestigious universities around the world have fully embraced online learning as a way to ensure the continuity of their education [3].

Studies have revealed that common infectious disease outbreaks such as COVID-19 are associated with psychological distress and even mental illness [4]. For students who already have an increased psychological distress [5.6], the quarantine period and distant education also increased their anxiety and stress levels. Initial studies showed that, especially in the first weeks of quarantine, students had very high stress levels [7]. Students also developed reactions linked to stress due to unknown serious infectious diseases [8]. Among the psychological effects of quarantine are detachment, anxiety, irritability, insomnia, poor concentration and indecisiveness, poor

() Şakir Tüfekçi, Hulusi Böke, 2021

doi:10.15561/20755279.2021.0104 performance and difficulty working or focusing, and especially burnout [9]. In addition, Branko [10] stated that stressful events experienced by university students could impact their learning burnout levels. According to one of the definitions made by Maslach \& Jackson, burnout is the result of chronic stress [in the workplace] that cannot be addressed successfully. Burnout among university students however is the fatigue caused by academic demands, a pessimistic feeling and apathy towards academic duties, and a sense of inadequacy as a student [12].

According to Schaufeli \& Taris [13], being a student cannot be considered the same as being an employee. However, from a psychological standpoint, the core activities of being a student can be considered as work [ex. certain tasks such as attending classes and doing homework, and passing classes]. Therefore, burnout can also happen to students who show signs of exhaustion due to feeling inadequate as a student. $[12,14]$.

According to the motivation theory of Bandura, self-sufficiency can be defined as people's subjective judgments about whether they can succeed in learning [15]. People's learning behavior is influenced by resulting factors and precursor behavior factors, whereas the former 
is the expectation of learning outcomes and the later is the expectation of learning efficiency [16]. In addition, Bandura's Social Cognitive Theory states that with the increase in students' sense of well-being and the amount of effort they put in to master challenging academic tasks and their self-sufficiency affects their academic achievement, and thus they can use their knowledge and skills more efficiently [15]. Some of the studies mention the positive impact of self-sufficiency [20] in academic achievement [19] among female university students [17] or students participating in online learning [18].

After the diagnosis of the covid-19 cases in Turkey, education in all universities was suspended for a short period of time, and then it was decided by the Higher Education Institution of Turkey that distant education would continue via digital means in universities as of March 23, 2020 [21]. Studies on the self-sufficiency of the students of the faculty of sports sciences are present in the literature [22-27]. When the literature related to general belief of self-sufficiency and burnout variables was examined, a negatively significant correlation between burnout and self-sufficiency beliefs was revealed [2830]. Students' learning habits have completely changed with the introduction of mandatory distant learning. With distant education replacing face-to-face classroom courses, it is a topic of curiosity for how the students' selfproficiency and burnout levels are shaped as a result.

The purpose of this study is to determine the perception of self-sufficiency and burnout levels of students studying in the faculty of sports sciences during the Covid-19 pandemic. The expected results of the study were an increase in the self-sufficiency level scores and a decrease in the burnout level scores of the students, which is the equivalent of a reverse correlation between the variables.

\section{Material and Methods}

\section{Participants}

This cross-sectional descriptive-correlational study was carried out at the Faculty of Sport Sciences of İnönü University in Turkey [the universe of the study [31]], between October and November of 2020. The Faculty of Sport Sciences continues to serve its students with its four departments [Physical Education and Sports Teaching, Coaching, Sports Management and Physical Education and Sports for the Disabled], with its nearly 30-year history and a student capacity of 947 [32]. Using the formula of Bartlett, Kotrlik and Higgins [33], a sample size of $0.05 \mathrm{~d}$ was calculated as at least 274 with a $95 \%$ confidence level. By adopting the stratified sampling method [34], at least sixty students from each grade (1-4) were included in the study, since the number of students in each class was close to one other. In order to carry out the study, Institutional Approval (21619327-622.01) from the Dean of the Sports Sciences Faculty and approval by the Social and Human Sciences Ethics Committee of İnönü University [2020 / 22-11] were obtained.

Research Design

Data Collection Tools

General self-sufficiency scale: The Turkish language form of the scale is a valid and reliable tool for measuring the current overall self-sufficiency of individuals aged 18 and over. The original 23-article form of the scale was developed by Sherer et al., [36]. Using a scale not only by translating it into a different language, but also performing validity and reliability studies on that scale is called adapting the scale to other languages and cultures. The adaptation into Turkish and the validity and reliability studies of the scale was carried out by Yildirım \& İlhan [38]. Yıldırım \& İlhan reported the total variance of the scale to be $41.5 \%$. The eigenvalue of the first factor was found to be 4.150 and the variance it explained was $20.2 \%$, the eigenvalue of the second factor was found to be 1.786 and the variance it explained was $11.9 \%$, and the eigenvalue of the third factor was found to be 1.114 and the variance it explained was $9.5 \%$. The internal consistency coefficient [Cronbach's alpha] of the whole scale was 0.80 and the test-retest reliability coefficient obtained from the data collected from 236 people who could be reached for the second time was 0.69 . The necessary permissions for the use of the scale were obtained after correspondence with the authors. Items $2,4,5,6,7,10,11,12,14,16$ and 17 on the scale are inversely graded. The total score of the scale can vary between 17-85; a higher score indicates an increased belief in self-sufficiency. It has been shown in previous studies that the internal reliability of the scale is acceptable [39-41].

Maslach burnout scale: It was developed by Schaufeli et al [43] with three dimensions: burnout [5 items], desensitization [5 items], and sufficiency [6 items] in order to determine burnout among students [12]. In this study, the Turkish version of the scale adapted by Çapri et al. [44] was used to measure student burnout. The Turkish version of the scale consists of three sub-factors, as in the original. During the reliability analysis of the Turkish version, 1 item was removed from the desensitization and 2 items from the sufficiency subscale. Cronbach alpha reliability coefficients of the Turkish version of the scale were reported to vary between 0.61 and 0.82 , indicating that the Turkish version of the scale is a reliable one. [44] In the Turkish version of the scale, students score their burnout levels on a 5 -point frequency scale $[1=$ never, $5=$ always]. High scores received from the burnout and desensitization subscale and low scores from the sufficiency subscale are indicators of high burnout [44]. It has been shown in previous studies that the internal reliability of the scale is acceptable $[45,46,41]$.

\section{Statistical Analysis}

The data were analyzed using SPSS 22 and Jamovi 1.2.22 statistical package software. Frequency and percentage values were used to determine the demographic characteristics [gender, department, class, family income, and disease-related status] of the students in the faculty of sports sciences. In addition to that, arithmetic mean and standard deviation data were presented to determine students' self-sufficiency perceptions and burnout levels. t-test was conducted to test whether the difference between the two unrelated sample averages was significant in terms of the variables of gender and contracting the disease. 
Also, one-way analysis of variance (ANOVA) was used to determine whether there was a significant difference between the variables of department, class, and family income, and whether there was a difference between the averages of the groups [47]. Pearson correlation coefficient was calculated to determine the direction and amount of the correlation between self-sufficiency perceptions and burnout levels of students. T test, variance analysis and Pearson correlation analysis were used in the analysis of the data. To figure out if the students' levels of burnout were predicted by perceived self-sufficiency, multiple regression analysis was conducted. Before the multiple regression analysis, statistical assumptions were checked [sample size $\mathrm{N} \geq 50+8 \mathrm{~m}$; normal distribution, whether there is a multiple linearity problem $(\mathrm{r}=\leq .80)$, whether the data is less than $5 \%$, etc.] [48]. And since no problems were encountered, the analysis continued. In these analyzes, each of the burnout subscale scores was considered as a dependent variable, and the subtest scores of the general self-sufficiency scale as independent variables. While interpreting the analyzes, regression coefficients, standardized regression coefficients, t-test results for regression coefficients, multiple correlation coefficients and explanation coefficients were taken into account. In regression analysis, since dependent and independent variables should be continuous variables with at least equal spacing, excluding one of the levels [category] of the variables of gender, department, class, family income and having coronavirus disease, the dummy variable produced one less of the number of levels is transformed and analyzed. In the interpretation of the analysis, Cohen's d [49] and partial eta square ( $\eta p 2)$ were taken as reference in evaluating the strength of the relations with $\mathrm{p}<.05$ value. According to Stevens [50], the value was taken as small for $\eta p^{2} \leq 0.01$, medium for $\eta p^{2}=$ 0.06 , and large for $\eta p^{2}=0.14$.

\section{Results}

\section{Characteristics of Participants}

Scores of the students from the "Self-sufficiency Perception Scale" are above average, and the scores for "Burnout Level Scale" are below average (Table 1).

Correlation Scores for Perception of Self-sufficiency and Burnout Scale Sub-Dimensions

Correlation analysis results for the sub-dimensions of the perception of self-sufficiency and burnout level scale are presented in Table 2. It was understood that the sub-dimensions of the perception of self-sufficiency and the level of burnout were positively and significantly correlated with each other. The sub-dimensions of the scales were negatively and significantly correlated with each other $(\mathrm{p}<.05)$.

Multiple Regression Analysis for self-sufficiency Perception and Burnout Level Scale Scores

Table 1. Perception of Self-sufficiency and burnout level scale sub-dimension scores

\begin{tabular}{llllll}
\hline Scale & Dimensions & M & SD & Minimum-Maximum & $\begin{array}{l}\text { Effect size of dimensions } \\
\text { [Cohen'd] }\end{array}$ \\
\hline \multirow{3}{*}{ Self-sufficiency } & Baseline & 4.02 & .55 & $1,89-5$. & $.22[\mathrm{~B}-\mathrm{Y}]$ \\
& Resilience & 3.89 & .62 & $1,20-5$. & $.70[\mathrm{~B}-\mathrm{S}]$ \\
& Perseverance & 3.59 & .66 & $1-5$ & $.46[\mathrm{Y}-\mathrm{S}]$ \\
& Total & 66.53 & 8.62 & $29-85$ & $.16[\mathrm{~T}-\mathrm{D}]$ \\
Burnout & Burnout & 2.68 & .96 & $1-5$ & $.49[\mathrm{~T}-\mathrm{Y}]$ \\
& Desensitization & 2.52 & 1.01 & $1-5$ & $.29[\mathrm{D}-\mathrm{Y}]$ \\
& Competence & 2.27 & .67 & $1-4.5$ & \\
\hline
\end{tabular}

Note: B [Baseline], Y [Resilience], S [Persevereance], T [Burnout], D [Desensitization], Y [Competence]

Table 2. Correlation matrix for the total score sub-dimensions of the perception of self-sufficiency and burnout level scale

\begin{tabular}{|c|c|c|c|c|c|c|c|c|}
\hline Dimensions & Self-S. & Baseline & Resilience & Perseverance & Burnout & Burnout & Desensitization & Competence \\
\hline Self-sufficiency & 1 & & & & & & & \\
\hline Baseline & $.929^{* *}$ & 1 & & & & & & \\
\hline Resilience & $.860^{* *}$ & $.681^{* *}$ & 1 & & & & & \\
\hline Perseverance & $.663^{* *}$ & $.461^{* *}$ & $.457^{* *}$ & 1 & & & & \\
\hline Burnout & $-.457^{* *}$ & $-.406^{* *}$ & $-.441^{* *}$ & $-.274^{* *}$ & 1 & & & \\
\hline Burnout & $-.353^{* *}$ & $-.305^{* *}$ & -. $357^{* *}$ & $-.208^{* *}$ & $.886^{* *}$ & 1 & & \\
\hline Desensitization & $-.339^{* *}$ & $-.320^{* *}$ & $-.325^{* *}$ & $-.159^{* *}$ & $.890^{* *}$ & $.667^{* *}$ & 1 & \\
\hline Competence & $-.519^{* *}$ & $-.448^{* *}$ & $-.475^{* *}$ & $-.385^{* *}$ & $.713^{* *}$ & $.434^{* *}$ & $.540^{* *}$ & 1 \\
\hline
\end{tabular}

**. Correlation is significant at the 0.01 level [2-tailed]. 
Multiple regression analysis was performed to determine how much of the variance in perception of general self-sufficiency and burnout levels can be explained by dummy variables [Tables 3,4$]$. The choice of predictors entered into the regression model was based on both theory and the predictive power of each variable. Gender, department, class, family income status and contraction of coronavirus were considered independent variables. Dummy variable columns were created by assigning value (1) to the category to be analyzed and (0) to the others. One of the variables was taken as the reference (constant) and general self-efficacy and burnout scores were assigned as dependent variables. The categories of the relevant variable were considered as independent variables and regression analysis was performed.

The relative importance order of the predictor

Table 3. Multiple regression analysis results predicting self-sufficiency perception level with dummy variables

\begin{tabular}{|c|c|c|c|c|c|c|c|}
\hline Predictor (Variable) & Categories & B & Standard Error & $\beta$ & $\mathbf{t}$ & p & Adj $R^{2}$ (cum) \\
\hline \multirow{2}{*}{ Gender } & (Fixed) Female & 65.331 & .791 & - & 82.543 & .000 & \multirow{2}{*}{.007} \\
\hline & Male & 1.814 & 970 & .099 & 1.870 & .062 & \\
\hline \multirow{4}{*}{ Department } & (Fixed) ESTPD & 67.585 & .954 & - & 70.816 & .000 & \multirow{4}{*}{-.003} \\
\hline & PEST & -1.926 & 1.615 & -.074 & -1.193 & .234 & \\
\hline & C & -.752 & 2.671 & -.016 & -.282 & .778 & \\
\hline & SM & -1.283 & 1.122 & -.073 & -1.144 & .253 & \\
\hline \multirow{4}{*}{ Grade } & (Fixed) 4. Grade & 66.233 & .917 & - & 72.263 & .000 & \multirow{4}{*}{.030} \\
\hline & 1st Grade & 2.552 & 1.209 & .139 & 2.110 & $.036^{*}$ & \\
\hline & 2nd Grade & -.675 & 1.423 & -.030 & -.475 & .635 & \\
\hline & 3rd Grade & -1.633 & 1.282 & -.083 & -1.274 & .204 & \\
\hline \multirow{5}{*}{ Family income } & (Fixed) 7500 and above & 67.556 & 2.042 & - & 33.075 & .000 & \multirow{5}{*}{-.009} \\
\hline & $1500-2999 "$ & -1.343 & 2.126 & -.076 & -.632 & .528 & \\
\hline & $3000-4499 "$ & -.528 & 2.284 & -.025 & -.231 & .817 & \\
\hline & $4500-5999 "$ & -.399 & 2.553 & -.013 & -.156 & .876 & \\
\hline & $6000-7499 "$ & -1.222 & 3.030 & -.029 & -.403 & .687 & \\
\hline \multirow{2}{*}{$\begin{array}{l}\text { Contraction of } \\
\text { coronavirus }\end{array}$} & (Fixed) No & 66.429 & .486 & - & 136.544 & .000 & \multirow{2}{*}{-.002} \\
\hline & Yes & 1.019 & 1.483 & .037 & .687 & .492 & \\
\hline
\end{tabular}

$*_{p}<.05$; ESTPD: Exercise and Sports Training for People with Disabilities; PEST: Physical Education and Sports Teaching; C: Coaching; SM: Sports Management

Table 4. Multiple regression analysis results that predict the burnout levels with dummy variables

\begin{tabular}{|c|c|c|c|c|c|c|c|}
\hline Predictor (Variable) & Categories & B & Standard Error & $\beta$ & $\mathbf{t}$ & $\mathbf{p}$ & Adj $R^{2}$ (cum) \\
\hline \multirow{2}{*}{ Gender } & (Fixed) Female & 33,314 &, 901 & & 36,974 &, 000 & \multirow{2}{*}{.002} \\
\hline & Male & $-1,011$ & 1,104 &,- 049 &,- 916 &, 360 & \\
\hline \multirow{4}{*}{ Department } & (Fixed) ESTPD & 33.585 & 1.068 & - & 31.452 & .000 & \multirow{4}{*}{.032} \\
\hline & PEST & 2.256 & 1.807 & .076 & 1.248 & .213 & \\
\hline & C & 3.248 & 2.989 & .060 & 1.087 & .278 & \\
\hline & SM & -2.195 & 1.255 & -.110 & -1.749 & .081 & \\
\hline \multirow{4}{*}{ Grade } & (Fixed) 4. Grade & 34.174 & 1.037 & - & 32.958 & .000 & \multirow{4}{*}{.043} \\
\hline & 1st Grade & -4.364 & 1.368 & -.210 & -3.189 & $.002 *$ & \\
\hline & 2nd Grade & -.912 & 1.610 & -.035 & -.567 & .571 & \\
\hline & 3rd Grade & .226 & 1.450 & .010 & .156 & .876 & \\
\hline \multirow{5}{*}{ Family income } & (Fixed) 7500 and above & 27.944 & 2.287 & - & 12.220 & .000 & \multirow{5}{*}{.028} \\
\hline & $1500-2999 "$ & 5.815 & 2.380 & .290 & 2.443 & $.015^{*}$ & \\
\hline & $3000-4499 "$ & 3.222 & 2.557 & .133 & 1.260 & .208 & \\
\hline & 4500-5999" & 2.774 & 2.858 & .082 & .971 & .332 & \\
\hline & $6000-7499 "$ & 5.389 & 3.392 & .111 & 1.589 & .113 & \\
\hline \multirow{2}{*}{$\begin{array}{l}\text { Contraction of } \\
\text { coronavirus }\end{array}$} & (Fixed) No & 32.619 & .552 & - & 59.082 & .000 & \multirow{2}{*}{-.000} \\
\hline & Yes & .197 & 1.683 & .006 & .117 & .907 & \\
\hline
\end{tabular}

* $p<.05$; ESTPD: Exercise and Sports Training for People with Disabilities; PEST: Physical Education and Sports Teaching; C: Coaching; SM: Sports Management 
Table 5. Testing the effect of burnout level dimensions on self-sufficiency using multiple regression

\begin{tabular}{llllllll}
\hline Predictor [Variable] & Categories & $\mathbf{B}$ & Standard Error & $\boldsymbol{\beta}$ & $\mathbf{t}$ & $\mathbf{p}$ & Adj $\mathbf{R}^{\mathbf{2}}$ [cum] \\
\hline \multirow{3}{*}{ Baseline } & Fixed & 4.959 & .099 & - & 49.851 & .000 & \\
& Burnout & -.066 & .037 & -.114 & -1.788 & .075 & .210 \\
& Desensitization & -.022 & .037 & -.040 & -.585 & .559 & \\
\multirow{2}{*}{ Resilience } & Competence & -.307 & .046 & -.377 & -6.644 & $.000^{*}$ & \\
& Fixed & 5.047 & .110 & - & 45.933 & .000 & \\
& Burnout & -.130 & .041 & -.199 & -3.192 & $.002^{*}$ & .247 \\
Perseverance & Desensitization & .015 & .041 & .025 & .371 & .711 & .247 \\
& Competence & -.370 & .051 & -.402 & -7.257 & $.000^{*}$ & \\
& Fixed & 4.510 & .125 & - & 36.193 & .000 & \\
& Burnout & -.090 & .046 & -.129 & -1.954 & .051 & .153 \\
\hline
\end{tabular}

$* p<.05$

variables on the dependent variables was given in Table 5. According to the results of the $t$ test at the significance level of 0.05 regarding the significance of the regression coefficients on the dependent variable, the states of significance are presented respectively. Accordingly, the order of relative importance for baseline is competence, burnout and desensitization.

\section{Discussion}

There are studies in literature reporting that selfsufficiency and burnout are significantly and inversely related to each other $[39,51,52]$. It was determined that the first graders were an independent significant predictor in terms of self-sufficiency perception and burnout level scores. In addition, it was determined that students from the lowest income families significantly predicted burnout level scores. It was understood that the pandemic did not have a significant negative impact on the students studying at the sports science faculty. In such a way that the fact that students transfer their active educational lifestyles to the isolation period in which they spend at their homes may be a positive predictor of this result.

It has been determined that first grade level scores are significant predictors of self-sufficiency perception and students with the lowest family income are significant predictors of the burnout level scores. Universities carry out a distant education programs under pandemic conditions, as in other educational institutions. Thus, it is thought that the fact that first-grade students have not yet experienced the difficulties of face-to-face education, this may explain the differentiation in self-sufficiency perception and burnout level scores. In addition, the burnout level scores of the students with the lowest family income being higher, considering the conditions they are in, might be an indication that they may experience difficulties due to their socio-economic status during the pandemic.

It was understood that the dimension of competence was a significant predictor of the baseline, resilience and perseverance dimensions. When we look at the studies conducted, it can be seen that the concepts of competence and self-sufficiency were usually discussed together [36, $53,54]$. So much so that the interaction of these two concepts with each other and the tendency to mention them together corresponds with the finding of the study. This can be explained by the significant prediction of all three dimensions of self-sufficiency.

Although pre-pandemic studies in the literature [55, $56,57]$ on the self-sufficiency and burnout of university students and young people are present, there was no study in which general self-sufficiency and burnout were directly related and predicted in terms of subdimensions during the pandemic. Previous researchers have confirmed a correlation between self-sufficiency and burnout $[43,58,59,60]$. Another study conducted with university students showed that all correlations between academic burnout and self-sufficiency were statistically significant [56]. In a study conducted with high school students, it was reported that there were statistically significant and inverse correlations between general selfsufficiency and anxiety [61]. In a review study, academic self-efficacy was found to be moderately correlated with academic performance [62]. In a study conducted with university students in Spain, it was found that there is an inversely proportional correlation between anxiety and self-sufficiency [63]

In a study conducted with university students, it was revealed that the majority had moderate or low selfsufficiency to deal with the COVID-19 outbreak [64]. It is known that people with poor self-sufficiency tend to choose negative emotional regulation strategies to cope with negative emotions when they are distressed, but individuals with high self-sufficiency tend to demonstrate positive approaches to improve their emotional regulation $[65,66]$. Some studies have shown that self-sufficiency has a direct effect on mental health such as depression and anxiety [65, 67]. In the study, it was reported that university students had concerns about their academic success, health and lifestyle due to the pandemic [68]. The 
anxiety of university students was confirmed by previous researchers in which it was revealed that anxiety disorders are more likely to occur and worsen in the absence of interpersonal communication $[69,70]$.

\section{Conclusion}

As a result, it was determined that during the Covid-19 pandemic, the students of the faculty of sports sciences had a self-sufficiency score above average and this score was in an inverse correlation with the dimensions of burnout perceptions. It can be suggested that students' perception of self-sufficiency and burnout levels should be studied around different variables, and their correlations should be examined and predicted [regression].

\section{Conflicts of Interest}

The authors declare no conflict of interest.

\section{References}

1. UNESCO. Global education coalition [Internet]. 2020 [cited 2020 Dec 11]. Available from: https://en.unesco.org/covid19/ educationresponse/globalcoalition

2. ChungE,NoorNM,MathewVN.Areyouready?AnAssessment of Online Learning Readiness among University Students. Int J Acad Res Progress Educ Dev. 2020;9(1):301-317. https://doi.org/10.6007/IJARPED/v9-i1/7128

3. Chung E, Subramaniam G, Dass LC. Online Learning Readiness among University Students in Malaysia amidst COVID-19. Asian J Univ Educ. 2020;16(2):46-58. https://doi.org/10.24191/ajue.v16i2.10294

4. Bao Y, Sun Y, Meng S, Shi J, Lu L. 2019$\mathrm{nCoV}$ epidemic: Address mental health care to empower society. Lancet. 2020;395(10224). https://doi.org/10.1016/S0140-6736(20)30309-3

5. American College Health Association. American College Health Association: National College health assessment II: Reference group executive summary spring 2019 [Internet]. 2019 [cited 2020 Dec 11]. Availablefrom:https://www.acha. org/documents/ncha/NCHAII_spring_2019_us_reference_ group_executive_summary.pdf

6. Bayram N, Bilgel N. The prevalence and sociodemographic correlations of depression, anxiety and stress among a group of university students. Soc Psychiatry Psychiatr Epidemiol. 2008;43(8):667-72. https://doi.org/10.1007/s00127-008-0345-x

7. Karalis T, Raikou N. Teaching at the times of COVID-19: Inferences and Implications for Higher Education Pedagogy. Int J Acad Res Bus Soc Sci. 2020;10(5):479-493. https://doi.org/10.6007/IJARBSS/v10-i5/7219

8. Samantha Kelly B, Rebecca D, Richard A, Gideon James R, Neil G. A systematic, thematic review of social and occupational factors associated with psychological outcomes in healthcare employees during an infectious disease outbreak. J Occup Environ Med. 2018;60(3):248-257. https://doi.org/10.1097/JOM.0000000000001235

9. Brooks SK, Webster RK, Smith LE, Woodland L, Wessely S, Greenberg N, et al. The psychological impact of quarantine and how to reduce it: rapid review of the evidence. The Lancet, 2020;395:912-20. https://doi.org/10.1016/S0140-6736(20)30460-8

10.Branko S. The syndrome of burnout, self-image, and anxiety with grammar school students. Horizons Psychol. 2001;10(2):21-32.

11. Maslach C, Jackson SE. The measurement of experienced bumout. J Occup Behav. 1981;2:99-113.

12.Schaufeli WB, Martinez I, Marques-Pinto A, Salanova $\mathrm{M}$, Bakker $\mathrm{AB}$, Marque's-Pinto $\mathrm{A}$, et al. Burnout and engagement in university students: A cross-national study. $J$ Cross Cult Psychol. 2002;33:464-481.

13.Schaufeli WB, Taris TW. The conceptualization and measurement of burnout: common ground and worlds apart. Work Stress. 2005;19(3):256 62 . https://doi.org/10.1080/02678370500385913

14.Meier SF, Schmeck RR. The burned-out college student: a descriptive profile. J Coll Student Pers. 1985;1:63-9.

15.Bandura A. Self-efficacy mechanism in human agency. Am Psychol. 1982;37(2):122-147.

16.Bandura A. Regulation of cognitive processes through perceived self-efficacy. Dev Psychol. 1989;25(5):729-735.

17.Betz N, Schifano RS. Evaluation of an intervention to increase realistic self-efficacy and interests in college women. $J$ Vocat Behav. 2000;56:35-52. https://doi.org/10.1006/jvbe.1999.1690

18.Fletcher KMM. Evaluating an intervention to build online learning self-efficacy [Doctoral Thesis]. Walden University; 2005.

19.Freedman A. Effects of a multicomponent group intervention on the self-efficacy and academic achievement of at-risk undergraduates [Doctoral Thesis]. The University of Wisconsin-Madison; 1996.

20.Wei Y. The measurement and intervention of college students' learning self-efficacy. Psychol Sci. 2004;27(4):905-908.

21.YÖK. Basın açılklaması [Internet]. 2020 [cited 2020 Dec 11]. Available from: https://www.yok.gov.tr/Sayfalar/ Haberler/2020/universitelerde-uygulanacak-uzaktanegitimeiliskin-aciklama.aspx

22.Eroğlu O, Yıldırım Y, Şahan H. Examination of the relationship between academic self-efficacy and academic motivation levels of students in sports sciences faculty: Akdeniz University example. The Journal of Turkish Sport Science. 2017;1(1):38-47.

23.Şahan H, Uğurlu A, Gülşen B, Varol İ. Determination of self-efficacy beliefs of students studying at Akdeniz University sports sciences faculty. Mediterranean Journal of Sports Science. 2018;1(2):67-73. https://orcid.org/0000-0002-4828-6285.

24.Ünlü H, Erbaș MK. Academic self-efficacy and professional concerns of physical education teacher candidates. Turkey Journal of Sports Science. 2018;2(1):15-25.

25.Küçük Kılıç S, Cỉhan H, Öncü E. The metacognitive learning strategies, academic self-efficacy and attitudes of physical education teacher candidates towards the teaching profession. Sports Science Journal. 2016;26(3):77-89. https://doi.org/10.17644/sbd.237580

26.Türkekul K, Sarıkabak M. Examining the relationship between the emotional intelligence levels and academic selfefficacy of physical education and sports teacher candidates. International Journal of Current Educational Research. 2019;5(1):52-69.

27.Eroğlu O, Yıldırım Y. Determination of academic self-efficacy levels of physical education and sports teacher candidates. Turkey Journal of Sports Science. 2018;2(2):67-73. https://https://doi.org/10.32706/tusbid.419468

28.Salanova M, Peiró JM, Schaufeli WB. Self-efficacy 
specificity and burnout among information technology workers: An extension of the job demand-control model. Eur J Work Organ Psychol. 2002;11(1):1-25. https://doi.org/10.1080/13594320143000735

29.Tang CSK, Au WT, Schwarzer R, Schmitz G. Mental health outcomes of job stress among Chinese teachers: Role of stress resource factors and burnout. . J Organ Behav Int $J$ Ind Occup Organ Psychol Behav. 2001;22(8):887-901. https://doi.org/10.1002/job.120

30. Yang HJ, Farn CK. An investigation the factors affecting MIS student burnout in technical-vocational college. Comput Human Behav. 2005;21(6):917-32. https://doi.org/10.1016/j.chb.2004.03.001

31.Gürbüz S, Şahin F. Research methods in social sciences. Ankara: Seçkin Publishing; 2016.

32.İnönü University. History of sports science faculty [Internet]. 2020 [cited 2020 Dec 20]. Available from: http://www.inonu. edu.tr/tr/sporbilimleri/1609/menu?m=5038

33. Bartlett JE, Kotrlik JW, Higgins C. Organizational research: Determining appropriate sample size for survey research. Inf Technol Learn Perform. 2001;19:43-50.

34.Johnson B, Christensen L. Educational research: quantitative, qualitative and mixed approaches. Demir S, editor. Ankara: Educational Book; 2014.

35.Sherer M, Maddux JE, Mercandante B, Prentice-Dunn S, Jacobs B, Rogers RW. The self-efficacy scale: Construction and validation. Psychol Rep. 1982;51(2):663-71. https://doi.org/10.2466/pr0.1982.51.2.663

36.Chen G, Gully SM, Eden D. Validation of a new general selfefficacy scale. Organ Res Methods [Internet]. 2001 [cited 2019 Apr 11;4(1):62-83. Available from: https://journals. sagepub.com/doi/pdf/10.1177/109442810141004

37. Karakoç FY, Dönmez L. Basic principles in scale development studies. Medical Education World, 2014;13(40): 39-49. https://doi.org/10.25282/ted.228738

38. Yıldırım F, İlhan İÖ. Validity and reliability study of the Turkish form of the general self-efficacy scale. Turkish Journal of Psychiatrist [Internet]. 2010 [cited 2019 May 10];21[4]:301-8. Available from: http://www.turkpsikiyatri. com/pdf/c21s4/301-308.pdf

39.Arslan A. Examining the social anxiety and general self-efficacy perceptions of health services vocational school students in terms of various variables. Int e-Journal Educ Stud. 2019;3(6):78-96. https://https://doi.org/ 10.31458/iejes.524860

40.Özgözgü S, Bektaş M, Arıkan F, Şimşek H. General selfefficacy beliefs and organizational identification perception of school counselors. Elem Educ Online. 2017;16(3).

41. Yurdakul A, Bostancı AB. The relationship between teachers 'views of schools' organizational narcissism and their selfefficacy perceptions. Kirıkkale University Journal of Sos Science. 2016;6(1):109-26.

42.Schaufeli WB, Salanova M, Gonzalez-Roma V, Bakker A. The measurement of burnout and engagement: A confirmatory factor analytic approach. J Happiness Stud. 2002;3:71-92.

43.Schaufeli WB, Martinez I, Marques-Pinto A, Salanova M, Bakker A. Burnout and engagement in university students: A cross-national study. Journal of Cross-cultural Studies. 2002;33:464-81. https://doi.org/10.1177/0022022102033005003

44.Çapri B, Gündüz B, Gökçakan Z. Adaptation of the Maslach burnout inventory-student form into Turkish: a validity and reliability study. Çukurova University Journal of Education Faculty. 2011;40(1):134-47.

45.Tuna HM, Olgun N. The role of perceived social support in the state of burnout seen in the relatives of patients caring for stroke patients. Hacettepe University Journal of Nursing Faculty. 2010;17(1):41-52.

46.Aydın D, Akay B, Baydemir S. Burnout in nursing students and influencing factors. Journal of Düzce University Health Science Institute. 2017;1(1):19-23.

47.Büyüköztürk Ş. Scientific research methods. 4th ed. Ankara: Pegem Academy; 2009.

48. Tabachnick BG, Fidell LS. Using multivariate statistics. 6th ed. Boston: Pearson; 2013.

49.Cohen J. Statistical power analysis for the behavioral sciences. 2nd ed. Hillsdale: NJ Lawrence Earlbaum Associates; 1988.

50.Stevens J. Applied multivariate statistics for the social sciences. Hillsdale: Lawrence Erlbaum Associates; 1992.

51.Bolat OI. Self-efficacy and burnout relationship: mediating effect of leader-member interaction. Ege Akad Overview. 2011;11(2):255-66.

52.Karahan Ş, Balat GU. Investigation of self-efficacy perceptions and burnout levels of educators working in special education schools. Pamukkale University Journal of Education. 2011;29(29):1-14.

53.Luszczynska A, Scholz U, Schwarzer R. The general selfefficacy scale: multicultural validation studies. $J \quad$ Psychol. 2005;139(5):439-57. https://doi.org/10.3200/JRLP.139.5.439-457

54.Chen G, Goddard T, Casper WJ. Relating general and workspecific selfevaluations and work-related control beliefs to an expanded job attitudes criterion. Appl Psychol An Int Rev. 2004;53(3):349-70.

55.Capri B, Ozkendir OM, Ozkurt B, Karakus F. General selfefficacy beliefs, life satisfaction and burnout of university students. Procedia-Social Behav Sci. 2012;47:968-73. https://doi.org/10.1016/j.sbspro.2012.06.765

56.Charkhabi M, Abarghuei MA, Hayati D. The association of academic burnout with selfefficacy and quality of learning experience among Iranian students. Springerplus. 2013;2(1):677. https://https://doi.org/10.1186/2193-1801-2-677

57.Böke H, Doğan A, Kartal M. Researching the self-efficacy levels of individuals attending youth centers. J Glob Sport Educ Res. 2019;2(1):45-56.

58.Cherniss C. Role of professional self-efficacy in the etiology and amelioration of burnout. In: Shaufeli W, Maslach C, Marek T, editors. Professional burnout: recent development in theory and research. Washington DC: Taylor and Francis; 1993. p. 49-135.

59.Hallsten L. Burning out: a framework. In: Schaufel i W, Maslach C, Marek T, editors. Professional burnout Recent developments in theory and research. Washington, DC: Taylor and Francis; 1993.

60.Hobfoll S, Freedy J. Conservation of resource: a general stress theory applied to burnout. In: Schanfeli W, Maslach C, Marek T, editors. Professional burnout: recent developments in theory and research. Washington, DC: Taylor \& Francis; 1993. p. 115-129.

61.Tahmassian K, Moghadam NJ. Relationship between selfefficacy and symptoms of anxiety, depression, worry and social avoidance in a normal sample of students. Iran $J$ Psychiatry Behav Sci. 2011;5(2):91.

62.Honicke T, Broadbent J. The influence of academic self-efficacy on academic performance: A systematic review. Educ Res Rev. 2016;17:63-84. https://doi.org/10.1016/j.edurev.2015.11.002

63.Alemany-Arrebola I, Rojas-Ruiz G, Granda-Vera J, 
Mingorance-Estrada AC. Influence of COVID-19 on the perception of academic self-efficacy, state anxiety, and trait anxiety in college students. Front Psychol. 2020;11. https://doi.org/10.3389/fpsyg.2020.570017

64.Al-Qahtani AM, Ibrahim HA, Elgzar WT. Self-Efficacy at time of COVID-19 pandemic among Najran University students, kingdom of saudi arabia. Sylwan. 2020;164(8).

65.CastellaKDe,Platow,MichaelJ,TamirM,GrossJJ.Beliefsabout emotion: implications for avoidance-based emotion regulation and psychological health. Cogn Emot. 2017;32:773-795. https://doi.org/10.1080/02699931.2017.1353485

66. Bandura A. The role of self-efficacy in goal-based motivation. In: Locke EA, Latham GP, editors. New Developments in Goal Setting and Task Performance. Routledge: Taylor \& Francis Group; 2013. p. 147-157.

67.GallaBM,WoodJJ.Emotionalself-efficacymoderatesanxietyrelated impairments in math performance in elementary school-age youth. Pers Indiv Differ. 2012;52:118-122. https://doi.org/10.1016/j.paid.2011.09.012

68.Wang X, Hegde S, Son C, Keller B, Smith A, Sasangohar F. Investigating mental health of US college students during the COVID-19 pandemic: Cross-sectional survey study. J Med Internet Res. 2020;22(9): e22817. https://https://doi.org/10.2196/22817

69.Xiao F, Tang M, Zheng X, Liu Y, Li X, Shan H. Evidence for gastrointestinal infection of SARSCoV-2. Gastroenterology. 2020;158(6):1831-3. https://doi.org/10.1053/j.gastro.2020.02.055

70.Kmietowicz Z. Covid-19:"There is no alternative, " says Johnson, announcing new restrictions for England. BMJ. 2020;371:1-2. https://doi.org/10.1136/bmj.m4247

\section{Information about the authors:}

Şakir Tüfekçi; (Corresponding Author); https://orcid.org/0000-0002-7815-5710; sakir.tufekci@inonu.edu.tr; Sports Management Department, Inonu University; Malatya, Turkey.

Hulusi Böke; https://orcid.org/0000-0002-5728-680X; yakamoz8386@gmail.com; Yaşar Öncan Secondary School, Ministry of Education; Malatya, Turkey.

Cite this article as:

Tüfekçi Ş, Böke H. Examination of the perceptions of self-sufficiency and burnout levels of students of the sports science faculty during the COVID-19 pandemic. Physical Education of Students, 2021;25(1):28-35. https://doi.org/10.15561/20755279.2021.0104

This is an Open Access article distributed under the terms of the Creative Commons Attribution License, which permits unrestricted use, distribution, and reproduction in any medium, provided the original work is properly cited http://creativecommons.org/licenses/by/4.0/deed.en

Received: 14.12 .2020

Accepted: 02.02.2001; Published: 26.02.2021 